\title{
Assessment of suitability of facilities and competence of Higher National Diploma graduates in cattle production in College of Agriculture Lafia, Nasarawa State, Nigeria
}

\author{
Garba Emmanuel Ekele \\ Department of Agricultural Education, Federal University of Agriculture, Makurdi, Benue State, Nigeria. Email: \\ ekelegarba@gmail.com.
}

Copyright (C) 2017 Ekele. This article remains permanently open access under the terms of the Creative Commons Attribution License 4.0, which permits unrestricted use, distribution, and reproduction in any medium, provided the original work is properly cited.

Received 16th June, 2017; Accepted 12th July, 2017

\begin{abstract}
The purpose of this study was to assess the suitability of facilities and competence of Higher National Diploma graduates in cattle production in College of Agriculture, Lafia, Nasarawa State-Nigeria. A survey research design was used for this study. Four research questions guided the study. The population of the study was 51 which consist of 33 HND students, 9 lecturers, 3 instructors and 6 farm supervisors. The entire population was used for the study. The instrument for data collection was structured questionnaire with 27 competence items in cattle production and checklist for facilities/equipment and tools in the college. The Cronbach Alpha method was used to determine the internal consistency of the instrument which yielded reliability coefficient of 0.83 . Mean (x) and percentage were used to answer the research questions while checklist was employed to determine the adequacy of staff and availability/suitability of facilities/equipment. Findings from this study revealed that equipment/tools are grossly inadequate, graduates of HND animal production possesses low competency level in cattle production and that staff are inadequate for running the programme. It was therefore recommended amongst others that workshop and training be organized for graduates to improve their level of competency in cattle production.
\end{abstract}

Key words: Competence, College of Agriculture, production, suitability.

\section{INTRODUCTION}

Educational programme need assessment for effectiveness. Assessment is the process of gathering information for the purpose of decision making. It involves the collection of information about an individual's knowledge, skills, attitude, judgment, interpretation and using the data for taking relevant decisions about the individual, instructional process, curriculum or programme (Ugodulunwa, 2014). Educational assessment involves proper management of information, changes in what people learn, how they learn, where they learn and when they learn. This is often occasioned by emergent of technology which leads to changes in assessment process. These changes in mode of assessment according to Ekele (2013a) require that quality and competence of HND graduate be assured in assessment at all levels of education including Higher National Diploma level. The National Board for Technical Education (2007) states that National Diploma animal production students must have obtained a good National Diploma to qualify for admission into Higher National Diploma in Animal production.

Animal production as explained by Ekele (2011) refers to husbandry of such livestock as cattle, sheep and goat, poultry and pig. The author affirms that it involves nutrition and management practices in livestock production. Competent HND graduates in animal production are expected to be functional by creating opportunities for employment especially in cattle production (NBTE, 2007).

As stated by Ekele (2013b), competency involves psycoproductive skills where students are exposed to practice 
of skills and are expected to perform these skills in occupation in which they are employed. Onu (1999) further asserts that competency based education places premium on the ability of the students to perform the specific tasks associated with the programme. Performing the tasks means that the facilities available have to be suitable for any meaningful acquisition of skills on the job. Suitability of facilities as reported by Nwachukwu (2006) are facilities, equipment and instructional materials that are appropriate in transmitting knowledge and skills to the learner. The author explained that facilities assist in transmitting informative ideas and make the ideas to be more explicit for teaching and learning. Consequently, it is imperative that facilities are not only adequate but suitable to be used in training students. Obioma (2006) echoed similar view that no matter the strength of manpower resources in educational institutions, educational process of teaching and learning must require enough suitable facilities and equipment. Unfortunately, students come in contact with facilities and equipment only during the supervised work experience scheme (Osinem and Nworji, 2010). This ultimately affects their competency and performance level.

The ability of graduate of animal production to perform well arises from a repetitive process in which skill holders engage in their jobs, and this becomes part of the individual to the extent the performance becomes automatic. Payne(1991) identified the following areas of competencies in cattle production to include making a hay and silage for cattle, establish pasture for grazing, cow calf operation and use of paddocks. The author states that deworming cattle, castration, steaming of cattle, use of dips, growing of stocks and skill in baby beef in production are also competencies required by graduates of animal production for successful occupation in livestock industry. Ekele (2014) also identified branding and tattooing as entrepreneurial skills required by farmers in cattle production. The author emphasized that branding is done for the identification of cattle. The practice of, and competence in steaming up cattle involves putting the cow on a special (rich) diet to set all the organs in good order for milk production after birth. This happens about eight weeks to calving.

In the opinion of Aduku and Ekele (2015), synchronization of oestrus is also an important skill which is a controlled inducement of ovulation in farm animal so that all or a greater proportion of the animals come on heat at the same period. This technique according to the authors plays an important role in the application of artificial insemination; crystalline progesterone can be used for the inducement. In the context of this study, graduate of animal production who found themselves in the world of work are expected to focus on cattle production. Thus, the suitability of the impacts that graduate make in relation to the requirements of the world of work depends on the competence exhibited on the job by graduates. The researcher observed after preliminary investigation that faculties being used for training HND students are obsolete and may not be available or suitable for cattle production. This may have resulted to the incompetence of HND graduate of animal production as they could not raise cattle for profitable business. Further inquiry from the graduates as to why this situation exists revealed that the graduates tend to lay the blame on obsolete facilities and dearth of teaching staff. It becomes necessary therefore to assess suitability of facilities and level of competence of HND graduates in cattle production in College of Agriculture, Lafia, Nasarawa State, Nigeria. Specifically, the study determined the:

1. suitability of facilities for running animal production programme in College of Agriculture.

2. adequacy and availability of facilities for running animal production programme in College of Agriculture.

3. level of competence of HND graduates of animal production programme in cattle production.

4. adequacy of teaching staff (Lecturers and Instructors).

\section{Research questions}

1. How suitable are the facilities for running animal production progamme in College of Agriculture?

2. How adequate are the available facilities for running animal production progamme in College of Agriculture?

3. What is the level of competence of HND graduate of animal production in cattle production?

4. How adequate are the available teaching staffs for running animal production programme in College of Agriculture?

\section{MATERIALS AND METHODS}

Descriptive survey design was adopted for this study. It was conducted in Lafia, Nasarawa State, Nigeria. Nasarawa State is located in North Central Nigeria. Descriptive survey was used because it describes the characteristic features or facts about a given population. The design is therefore appropriate for the study since it collects and analyzes data from lecturers in Colleges of Agriculture and HND II students. The population of the study is 51 made up of 33 HND students, 9 lecturers, 3 instructors, and 6 farm supervisors. No sampling was carried out, the entire population was used. The instrument for data collection was a structured questionnaire titled: 'competence level of graduates in cattle production questionnaire (CGICPQ) and check list designed for the study: The questionnaire was used only for competency level of HND graduate while checklist 
Table 1. Mean and standard deviation of Lecturers, Instructors and Supervisors on the suitability of facilities for running animal production programme in College of Agriculture $(\mathrm{N}=18)$.

\begin{tabular}{llccc}
\hline S/No & Facilities & Mean $\overline{\mathbf{x}}$ & SD & Remarks \\
\hline 1 & Beef cattle unit & 3.81 & 0.59 & Suitable \\
2 & Dairy cattle unit & 3.81 & 0.69 & Suitable \\
3 & Milking parlour & 3.76 & 0.69 & Suitable \\
4 & Slaughter house & 4.00 & 1.02 & Suitable \\
5 & Feed mill with accessories & 3.86 & 0.46 & Suitable \\
6 & Silage pits & 3.81 & 0.59 & Suitable \\
7 & Biological pH meters & 1.63 & 0.61 & Not Suitable \\
8 & Goman dissecting sets & 3.76 & 0.67 & Suitable \\
9 & Surgeons dissecting sets & 3.85 & 0.44 & Suitable \\
10 & Rubber hand gloves & 3.83 & 0.45 & Suitable \\
11 & Scalpels & 3.76 & 0.59 & Suitable \\
12 & Bone breaker & 2.02 & 0.50 & Not Suitable \\
13 & Astall hearson dryer & 3.63 & 0.80 & Suitable \\
14 & Chance bovver dips & 2.12 & 0.61 & Not Suitable \\
15 & Sterilizer/autoclave & 3.85 & 0.48 & Suitable \\
16 & Dissecting trays & 3.81 & 0.56 & Suitable \\
17 & Dissecting boards & 3.76 & 0.67 & Suitable \\
18 & Desiccators & 3.78 & 0.66 & Suitable \\
19 & Light weight stereoscope & 3.80 & 0.63 & Suitable \\
20 & Post mortem knife & 3.85 & 0.48 & Suitable \\
21 & Scapula knives & 3.83 & 0.58 & Suitable \\
22 & Long scissors & 3.81 & 0.62 & Suitable \\
23 & Curved scissors & 3.85 & 0.48 & Suitable \\
24 & Long forceps & 3.81 & 0.53 & Suitable \\
25 & Scalpel holder & 3.78 & 0.55 & Suitable \\
26 & Aluminium equipment tray & 3.85 & 0.40 & Suitable \\
27 & Automatic syringes & 3.73 & 0.68 & Suitable \\
28 & Microscope binocular & 3.81 & 0.43 & Suitable \\
29 & Pocket hand lenses & 3.83 & 0.41 & Suitable \\
30 & Disposable syringes & 3.80 & 0.54 & Suitable \\
31 & Glass syringes & 3.86 & 0.46 & Suitable \\
32 & Deep freezers & 3.85 & 0.44 & Suitable \\
33 & Refrigerators & 3.8 & Suitable \\
34 & Electronics balances & 3.73 & 0.60 & Suitable \\
\hline & & & & \\
\hline
\end{tabular}

was used for adequacy of equipment/staff in the College of Agriculture. The questionnaire was subjected to face validation by three experts, two from the Department of Vocational Agriculture and Technology Education and one from Department of Animal Production all in the University of Agriculture, Makurdi. The internal consistency of the instrument was determined using Cronbach Alpha. A coefficient of 0.83 was obtained. Any item with mean value of 2.50 and above was considered high in competence, while any item with the mean value of less than 2.50 was considered low in competence. For availability, of facilities/tools/equipment, adequacy and availability of teaching staff, any item with $70 \%$ and above level of availability was considered as adequate and any item with less than $70 \%$ was considered inadequate. Any item with mean value of 2.50 and above was considered suitable and below 2.50 not suitable. Mean $(x)$ and percentages were used to answer the research questions.

\section{RESULTS}

\section{Research question 1}

How suitable and functional are the facilities for running animal production programme in College of Agriculture? Data presented in Table 1 revealed that the mean of thirty one (31) suitable facilities ranges from 3.76 to 4.00 . The standard deviation ranged from 0.40 to 0.70 
Table 2. Number and percentage of Instructors' response to available/tools, and equipment used for teaching animal production programme in College of Agriculture

\begin{tabular}{|c|c|c|c|c|c|}
\hline S/No & Equipment/tools & $\begin{array}{c}\text { Nos } \\
\text { Required }\end{array}$ & $\begin{array}{c}\text { Nos } \\
\text { Available }\end{array}$ & $\begin{array}{c}\text { Percentage } \\
(\%)\end{array}$ & Remarks \\
\hline 1 & Artificial insemination equipment & 2 & 0 & $0 \%$ & Inadequate \\
\hline 2 & Knapsack & 5 & 1 & $20 \%$ & Inadequate \\
\hline 3 & Weighing balance & 5 & 1 & $20 \%$ & Inadequate \\
\hline 4 & Ear notchers & 2 & 0 & $0 \%$ & Inadequate \\
\hline 5 & Tattooing machine & 2 & 0 & $0 \%$ & Inadequate \\
\hline 6 & Hoof trimmers & 2 & 1 & $50 \%$ & Inadequate \\
\hline 7 & Burdizzo & 6 & 1 & $50 \%$ & Inadequate \\
\hline 8 & Rubber bairds & 30 & 5 & $16.6 \%$ & Inadequate \\
\hline 9 & Heaters and thermometers & 10 & 2 & $10 \%$ & Inadequate \\
\hline 10 & Foot mails and floor brushers & 2 & 1 & $50 \%$ & Inadequate \\
\hline 11 & Feed troughs and water trough & 10 & 5 & $50 \%$ & Inadequate \\
\hline 12 & Small drinkers & 10 & 6 & $60 \%$ & Inadequate \\
\hline 13 & Spraying equipment & 2 & 1 & $50 \%$ & Inadequate \\
\hline 14 & Record books & 2 & 2 & $100 \%$ & Adequate \\
\hline 15 & Designed forms and stamps & 2 & 2 & $100 \%$ & Adequate \\
\hline 16 & Kjedahl digestion apparatus & 2 & 0 & $0 \%$ & Inadequate \\
\hline 17 & Oven and kjedahl flask & 2 & 1 & $50 \%$ & Inadequate \\
\hline 18 & Spectrophotometer (Atomic absorption) & 2 & 0 & $0 \%$ & Inadequate \\
\hline 19 & Soxhlet apparatus & 2 & 1 & $50 \%$ & Inadequate \\
\hline 20 & Flame photometer (calorimeter) & 3 & 1 & $33.3 \%$ & Inadequate \\
\hline 21 & Syringe/needles & 10 & 4 & $40 \%$ & Inadequate \\
\hline 22 & Microscopes & 15 & 3 & $20 \%$ & Inadequate \\
\hline 23 & Slaughter's slap \& slaughter kit & 5 & 2 & $40 \%$ & Inadequate \\
\hline 24 & Scape blade and prepared slides & 10 & 3 & $30 \%$ & Inadequate \\
\hline 25 & Staining reagent and microscopic slides & 10 & 2 & $20 \%$ & Inadequate \\
\hline 26 & Suture materials iodine & 15 & 5 & $33.3 \%$ & Inadequate \\
\hline 27 & Drying equipments & 6 & 1 & $16.6 \%$ & Inadequate \\
\hline 28 & Branding iron and stethoscope & 2 & 1 & $50 \%$ & Inadequate \\
\hline 29 & Drenching gun and hoof trimmers & 5 & 1 & $20 \%$ & Inadequate \\
\hline
\end{tabular}

indicating that the respondents were not very far from the mean or one another in their responses. However, three facilities were rated not suitable (mean value fall below 2.50) namely Biological PH meters, Bone breakers and chance bovver dips. This could possibly be due to their non-functionality.

\section{Research question 2}

How adequate are the available facilities for running animal production programme in college of Agriculture? Data presented in Table 2 showed that of the 29 equipment/tools, only designed forms/stamps and record books were found adequate. The remaining 27 equipment/tools were inadequate in the college. These facilities scored below $70 \%$, hence, they are inadequate.

\section{Research question 3}

What is the level of competence of HND graduates of animal production in cattle production? Analysis of data as presented in Table 3 revealed that of the 27 competency items on cattle production, 13 (thirteen) were rated low (mean do not meet the cut-off point of 2.50), hence, the graduate have low competence in these items. 14 items have mean ranging from 3.16 to 3.44 which indicates that graduates possessed high competence in these items as rated by supervisors. The standard deviation (SD) ranged from 0.36 to 0.49 , indicating that the respondents were not very far from the mean or one another in their responses.

\section{Research question 4}

How adequate is the available teaching staff for running animal production programme in College of Agriculture? Data presented in Table 4 showed the availability and adequacy of teaching staff by checklist. All the categories of teaching staff for animal production were found 
Table 3. Mean and standard deviation of supervisors ratings on the level of competence of HND graduates of animal production in cattle production $(\mathrm{N}=6)$.

\begin{tabular}{|c|c|c|c|c|}
\hline S/No & Items competencies on cattle production & Mean (x) & SD & Remarks \\
\hline 1 & Formulate and balance cattle ration & 3.33 & 0.48 & High \\
\hline 2 & Make hay and silage for cattle & 3.33 & 0.48 & High \\
\hline 3 & Establish a pasture for grazing & 1.33 & 0.48 & Low \\
\hline 4 & Cattle fattening and finishing & 3.33 & 0.48 & High \\
\hline 5 & Constrict and use of silo in beef cattle production & 3.33 & 0.46 & High \\
\hline 6 & Skill in baby beef production & 3.22 & 0.42 & High \\
\hline 7 & Cow calf operation & 1.16 & 0.38 & Low \\
\hline 8 & Growing of stockers & 3.22 & 0.43 & High \\
\hline 9 & Use of paddocks, feed bunks and water trough & 3.16 & 0.38 & High \\
\hline 10 & Use of dips, weigh bridger and squeeze chute. & 3.16 & 0.38 & High \\
\hline 11 & Deworm cattle & 1,16 & 0.38 & Low \\
\hline 12 & Hoof trimming of cattle & 1.22 & 0.42 & Low \\
\hline 13 & Castrate and spray cattle & 1.22 & 0.43 & Low \\
\hline 14 & Steaming up in dairy cattle & 3.22 & 0.42 & High \\
\hline 15 & Breeding efficiency in cattle & 1.15 & 0.37 & Low \\
\hline 16 & Carryout essential steps in developing a profitable breeding programme & 3.20 & 0.45 & High \\
\hline 17 & $\begin{array}{l}\text { Ability to carry out the process of Reproductive development in dairy bull and } \\
\text { cow e.g oestrus synchronization }\end{array}$ & 1.99 & 0.36 & Low \\
\hline 18 & Ability to carry out mating system e.g artificial insemination & 1.34 & 0.37 & Low \\
\hline 19 & Ability to classify the breeds of cattle into exotic and tropical & 3.44 & 0.48 & High \\
\hline 20 & Identify the distinctive characteristics of exotic and indigenous breeds & 2.23 & 0.44 & High \\
\hline 21 & Identify types and methods of cattle selection & 1.44 & 0.36 & Low \\
\hline 22 & $\begin{array}{l}\text { Ability to describe genetic effects of pedigree and carry out individual and family } \\
\text { selection }\end{array}$ & 1.34 & 0.48 & Low \\
\hline 23 & Identify the various factors to be considered in establishing a cattle herd & 1.21 & 0.42 & Low \\
\hline 24 & $\begin{array}{l}\text { Ability to identify and describe the following bull steer, stag, cow, heifer, calf, } \\
\text { yearling }\end{array}$ & 3.32 & 0.47 & High \\
\hline 25 & $\begin{array}{l}\text { Ability to classify cattle based on use stecker cattle, feeder cattle, slaughter } \\
\text { cattle, draught cattle. }\end{array}$ & 1.16 & 0.38 & Low \\
\hline 26 & Ability to plan and design dairy building & 3.18 & 0.39 & High \\
\hline 27 & $\begin{array}{l}\text { Capacity to construct various types of dairy buildings eg standion stall and barn, } \\
\text { freestalls and cattle buildings. }\end{array}$ & 1.23 & 0.42 & Low \\
\hline
\end{tabular}

inadequate because the percentage score of availability was less than $70 \%$. Therefore, the teaching staffs for animal production in the College were considered inadequate.

\section{Major findings of the study}

1. Some of the facilities available were not found suitable and functional (Biological $\mathrm{PH}$ meter, Bone breakers and Chance bovver dips) for running animal production programmes in the College.

2. It was found out from research question 2 that most of the equipment/tools required for the programme are grossly inadequate.

3. Graduates of the programme (HND) as revealed from research question 3 have low competence level in key areas of cattle production.
4. It was found out that all categories of staff needed for animal production were inadequate.

\section{DISCUSSION}

The finding that some of the facilities used for running of animal production programme in the College are not suitable was in consonance with the findings of Eya and Neboh (2001) who found out that facilities ought to be suitable for staff and students in the teaching and learning process. The finding that equipment and tools required for the programme are grossly inadequate was in agreement with the findings of Ogwo and Oranu (2006). The author affirmed that availability of equipments/tools when sufficient, dictates the pace of knowledge acquisition. The finding was also in line with the Ekwe (2002) who asserts that equipment/tools where 
Table 4._Number and percentage of teaching staff of animal production programme in College of Agriculture, Lafia, Nasarawa State.

\begin{tabular}{lcccl}
\hline Lecturers & Number Required & Number Available & \% Percentage & Remarks \\
\hline Chief Lecturer & 4 & 2 & $25 \%$ & Inadequate \\
Principal Lecturer & 4 & 1 & $25 \%$ & Inadequate \\
Senior Lecturer & 3 & 3 & $100 \%$ & Inadequate \\
Lecturer 1 & 5 & 2 & $25 \%$ & Inadequate \\
Lecturer 11 & 4 & 2 & $50 \%$ & Inadequate \\
Assistant Lecturer & 2 & 0 & $0 \%$ & Inadequate \\
Instructors & 4 & 2 & $50 \%$ & Inadequate \\
\hline
\end{tabular}

available transmits informative ideas and make idea to be explicit. The findings from that HND animal production graduates possessed low competencies in production was in agreement with the findings of Duncan and Grubb (2005) who found out that low skill in vocational agriculture is a limiting factor to high production. In support of the findings, Fatunsin (1996) agreed that high competence possessed in animal production encourages the use of psychomotor skills which leads to performance. The author further reiterates that psycho productive skills, competencies and abilities possessed at high level are better for performing tasks in animal production. The findings that all categories of staff were inadequate was in conformity with the findings of Omoreige (2006) who found out that it is worthless having a good curriculum for a school that is not adequately staffed (Lecturer and Instructors). Thus, adequacy of staff determines the effectiveness of teaching which in turn determine the performance of HND animal production graduates.

\section{Conclusion}

The quality of HND graduates from Colleges of agriculture depends on availability and functional facilities, tools/equipment and adequate staff students' ratio. The study has established the prevalence of inadequate facilities and staff. This had resulted to low competency level of the graduates in cattle production. The essence of the objectives of National Board for Technical Education for HND animal production graduates is to make them competent, productive and employer of labour. This objective is far from being realized with the findings from this study.

\section{Recommendations}

Based on the findings the following recommendations were made:

1. Ministry of Education with the assistant of state government should ensure adequate provision of equipment/tools and facilities for effective running of animal production programme in the College of Education.

2. Workshop and seminars should be organized where resource persons could train graduates in competencies required for cattle production.

3. Qualified staff should be recruited by Principal or Governing Council of the College. This will enhance the quality of teaching and learning on the College.

\section{CONFLICT OF INTEREST}

The authors declare that they have no conflict of interest.

\section{REFERENCES}

Aduku, A. B., \& Ekele, G. E. (2015). Skill improvement needs of farmers in cattle rearing for self-reliance in Nasarawa state. Journal of Agricultural Economics, Extension and Science. University of Agriculture Makurdi, Nigeria. (1), 203-210.

Duncan, G., \& Grubb, N. (2005). The nature of job training programme reviewed: technical assistant report: Berkeley, University of California at Berkeley 4, 5-9

Ekele, G. E. (2011). Evaluation of Higher National Diploma Animal production programme of Colleges of Agriculture in North Central Nigeria. Unpublished Ph.D thesis. Department of Vocational Education. University of Nigeria, Nsukka. PP 35.

Ekele, G. E. (2013a). Job entry skills in sheep and goat production for Senior Secondary School graduates in Kano State, Nigeria. Review of Education. Institute of Education Journal. University of Nigeria, Nsukka. 26(2), 35-46.

Ekele, G. E. (2013b). Evaluation of programme course content and facilities of HND Animal production programme of College of Agriculture, Yandev, Benue State. International journal of research in Science, Technology and Mathematics (IJRSTME, university of Jos, Nigeria) 1(1), 40-50.

Ekele, G. E. (2014). Entrepreneurial skills required for wealth creation by farmers for cattle production in Sokoto State. Taraba State University journal of Education Research and Production. 3(2), 5-9.

Ekwe, K. C. (2002). Evaluation of Instructional materials used for Teaching Business studies in Secondary Schools. The Delta State Experience. Business Education journal. 1(1), 2935.

Eya, P., \& Nebo, O. (2001). Evaluation of available instructional materials for the implementation of the UBE programme. 
Enugu Educational zone. The Nigeria Universal Basic Education journal. 1(2), 205-209

Fatunsin, L. O. (1996). Development and Standardization of performance - based test for assessing students in Agriculture in Secondary Schools in Ondo State. Unpublished Ph.D thesis. Department of Vocational Education, University of Nigeria, Nsukka. p. 28.

Nwachukwu, C. E. (2006). Designing appropriate methodology in Vocational and Technical Education for Nigeria. Nsukka, University Trust publishers. p. 47.

National Board for Technical Education (2007). Retrieved from www.nbte.gov.ng/download/ on 09/10/2016.

Obioma, G. (2006). Sustaining the culture of National Reform in Nigeria: Implications for curriculum change. $23^{\text {rd }}$ Distinguished lecture series. Otto/ijamikin, Ademiran Ogunsanya College of Education. 1, 7-9

Ogwo, B. A., \& Oranu, R. N. (2006). Methodology in Formal and Non-Formal Technical/Vocational Education. Enugu. Ijejas Printers \& Publishers Co. p. 52.
Omoreige, N. (2006). Inadequacies Teacher Education in Nigeria: The way out. Multidisciplinary journal of empirical Research (MULTIJER) (3), 45-49.

Onu, F. M. (1999). Development and Validation of a competency Based Rating Instrument (CBRI) for evaluating the teaching effectiveness of secondary school teachers of Agriculture in Enugu State, Nigeria. Unpublished Ph.D thesis. Department of Vocational Education. UNN. Pp. 20-30

Osinem, E. C \& Nworji, U. C. (2010). Students Industrial Work Experience in Nigeria. Concepts, principles and practice. Enugu. Cheston Agency Limited. Pp. 25-31

Payne, W. J. A. (1991). An Introduction to Animal husbandry in the Tropics (4 ${ }^{\text {th }}$ edition). England. Longman Group Limited.

Ugodulunwa, C. A. (2014). Quality Assurance in Research, Assessment and Evaluation in Nigeria. A led paper presented at $16^{\text {th }}$ national conference of the Association of Educational Researchers and Evaluators of Nigeria held from $14^{\text {th }}-18^{\text {th }}$ July. University of Calabar. p. 6. 